very agency for so magnificent a work. There would seem to exist no insuperable difficulties in the way of invigorating that institution, and giving it such increased powers of investigation, discussion, recommendation, and even of legislation, that it may become the prototype of that greater world clearing house for the advancement of the mutual interests, the rights and the peace of nations which all men desire.

In conclusion, we would do well to be on our guard lest the realization of the horrors of war should create an atmosphere of hysteria around this supreme problem of international justice. Horrible as this war is, it must not prompt us to recommend expedients for peace which might involve any fundamental denial of justice. We must remember that there are horrors of peace as well as of war. Where vice and wickedness flourish, where injustice reigns unrestrained, it is criminal to insist on enduring peace.

Furthermore, we must recognize that, humanly speaking, nothing is permanent. There can be no perpetual peace. It may be striven for only through eternal conflict with wrong. And to secure the triumph of justice between nations, men, at times, must be willing and eager to fight.

By an extraordinary paradox, then, war itself must sometimes be accepted as a righteous and an essential element of a just peace. Militarists, pacifists and all good patriots alike should fervently unite in the firm determination that so grim an element shall not have been employed in vain.

\title{
THE BASES OF A JUST AND ENDURING PEACE
}

By Franklin H. Giddings, Ph.D., LL.D., Columbia University, New York.

Peace at any price would be the abject surrender of justice and the abandonment of morality, and could never be an enduring peace. Peace at any price means the surrender of civilization, liberty, responsibility and self-respect. It means the exchange of a freeman's birthright for a villain's broth. In shame and humiliation we have to take an inventory of those individuals in our population that would make such surrender and would so barter. Rela- 
tively, however, they are not numerous and never can be. They are among those extreme variates from human normality, which range from persons of low intelligence and grotesque criminality at one end of the frequency curve, to mad geniuses and martyrs at the other end. All such variates, the good and the bad, the desirable and the undesirable, get crowded to the wall and exterminated when the struggle for existence is really severe, but when life is as soft as it has been in England and the United States for fifty or more years past, they are able to live and to propagate. Fortunately, they have never controlled public policy on a large scale, or for a long time, and they never will control it. Least of all will peace at any price men control. The normal man wants peace not as an end but as a means. He wants peace because he wants to feel that his wife and children are safe while he does his day's work. He wants peace if therewith he can enjoy liberty and a good conscience; otherwise he wants to fight, and fight he will, with a joy pure and undefiled. This is not mere argument. It is statistical fact which happens to fix and to define the possibilities of enduring peace. Variates from type are minorities, normal men are a majority. The normal majority will not accept peace at any price. They will fight. For the purposes of peace propaganda that hope to get somewhere the peace-at-any-price man is obstructive.

There can be no just and no enduring peace between absolutism and democracy.

The American Revolution was not taken seriously in the throne rooms of continental Europe. A desperately impoverished population of less than three million souls, dwelling three thousand miles from anywhere, could safely be let alone to indulge itself, for a time, in the odd conceits of republicanism. The experiment would probably fail, and, if it did not, Europe could at any time curb its power for mischief.

The French Revolution was another matter. That upheaval sent chills down royal spines. The guillotine in the Place de la Concorde was near enough to be seen and heard when one lay awake in the night. Also, it was known to be inexpensive, making no impossible demands upon the financial resources of a third estate, and was understood to be practical. It cut off two Bourbon heads of the first class and plenty of others only less respectable; and yet, and this was the worst of it, its operations were only an episode, 
The rest of the story is brief, and relatively uncomplicated. The human animal and his interests being what they are, the Napoleonic wars made inevitable the Prussian aggression of 1870-1871; and the creation of the German Empire by successful Prussia made inevitable the monstrous Prussian arrogance which, from the accession of William II until Verdun, fed itself upon dreams and plans of world empire. The boastful proclamation of this purpose, and the systematic creation of the most tremendous militaristic system ever seen or imagined, with declared intent to use it aggressively, made inevitable the alliance of Great Britain with France (her foe of a century ago) against Germany, her ally then against Napoleon.

So, at last, the giant democracies of western Europe and the giant absolutisms of central Europe confronted each other on the fields of France and Flanders in life and death grapple. The issue, that had been more or less confused, became sharply defined. Democracy or dynasty will be sovereign, from this time on.

The case of Russia is not less clear than the issue between France and Prussia. The man who until a month ago denied that this war is a conflict between democracy and dynasty because, forsooth, Russia was fighting as the ally of France and of Great Britain, was one of those publicists described in holy writ who darken council by words without knowledge. The Russian dynasty, Teutonic in sympathy and more than half Teutonic in blood, would have fought with Germany if it had dared. It did not dare because the Russian people, including the business classes, were ripe for revolution, and were in sympathy with the aspirations of the democratic peoples.

Therefore let the blazing truth about this war be repeated, emphasized, driven home, to every mind. This war is the life and death fight of dynasty at bay. It is the most portentous as it is the most gigantic and the most dreadful conflict in all human history, because it is the last stand of the massed and organized forces of despotism against liberty, enlightenment and progress. If it is won by the democratic peoples it is won forever.

If the democratic peoples are defeated, what then? Then fighting will continue. All the work of centuries must be done over again. Insurrections, rebellions, revolutions must once more be the chief interest of men worthy of the name. Whoso talks of peace will deserve and will get only the scorn of the brave and the just. 
Here, again, it is fact, not argument, that is presented. Mankind has not tasted self-government and individual liberty for nothing. A major number of human beings in western Europe and in America will not submit tamely to the absolutist rule from which they have for a hundred years believed themselves to have escaped. Less than ten years before the war began everybody was predicting that the existing generation would see liberal constitutional government established over the entire earth. Turkey, Persia, China, would be republics at least in name and under the stimulus of selfrespecting liberty would rapidly become republics in fact. Perhaps this forecast was a dream, but if it was, it will be dreamed again.

There is one more possibility to consider. If the war ends in a peace without victory, what may we expect? There are only two things that can happen, and therefore only two things that a reasoning mind can expect. The forces of democracy will more quickly recover and set about the business of preparing an adequate defence against the next onslaught of absolutism, or the forces of absolutism will more quickly recover and set about the business of preparation for the next war of aggression. The two sets of forces will not long remain in equilibrium. Peace without victory will be an armistice, nothing more.

The problem is now fully before us. We may look at it from any angle. We may turn it inside out and outside in. The issue remains specific, unalterable. There can be no enduring peace on this earth until absolutism is destroyed. A peace program that does not squarely face this fact is a pipe dream.

If we do face it squarely we shall think straight about the possibilities and practicalities of all proposed leagues to enforce peace.

A universal league, including all the sovereign nations would be nothing more or less than the existing state of affairs under another name. It would be the most absurd perpetual-motion machine ever yet experimented with. The relations of the nations to one another, as defined and regulated by the international law of the world as it stood on July 31,1914 , constituted a world league of peace, neither more nor less, and it went to smash. A league to keep the peace presumes that its component nations will honorably keep faith with one another. A league to enforce peace must be composed of nations that will both keep faith with one another and 
practically act in coöperation with one another against the law breaker. Practically, these requirements can be met and will be met only if the component nations of the league share a common civilization, hold a common attitude toward questions of right, liberty, law and polity, and share a sense of common danger threatening from nations whose interests, ambitions, moralities and politics are antagonistic.

Practically, therefore, there are now only two possibilities open to the would-be makers of the leagues to enforce peace. There can be no universal league. That would be nothing but the adoption of a sounding name and a platform of pious resolutions. There can be no coherent, workable league made up of both democratic and dynastic nations. Fellowship of the wolf with the lamb has not yet been invented. Peace between the hyena and the dog does not endure, and wild, or domesticated, asses have not ceased to be the prey of lions in the wilderness. But there can be a league of democratic nations to safeguard republican civilization in the world, and there can be a league of dynastic nations to perpetuate dynastic authority and power.

These two leagues exist now, and into one or the other of them every nation in the world will inevitably be drawn. One is a league to enforce peace, because peace will come and will endure when the other one of these leagues is crushed.

Happily the United States has dropped the fatuous belief that it could stand aside and, from safe isolation, watch the titanic struggle between liberty and despotism. In the moral order of the universe it is not permitted to a nation, any more than it is permitted to an individual, to be neutral upon the great fundamental issues of conduct. He who does not dare to stand for what in his inmost soul he believes to be right must surely die the second death of those who become the craven slaves to what they once held to be wrong. The United States will worthily play its part in the league of the democratic peoples to safeguard those political principles which the league of the thirteen original American states was the first power to proclaim. Pacifists, like the givers of indiscriminate alms, whom they mentally resemble, we may always have with us, but the American nation will not be a partner and accomplice of dynasty. 